Miłosz BUKWALT*

Uniwersytet Wrocławski

Instytut Filologii Słowiańskiej
Оригинални научни рад

Примљен: 08. 11. 2016.

Прихваћен: 10. 02. 2017.

\title{
ИСКУСТВО ДИЈАСПОРЕ У ИЗАБРАНИМ ЕСЕЈИМА ДАВИДА АЛБАХАРИЈА
}

\begin{abstract}
У овом чланку предмет су анализе Албахаријеви есеји из збирке Дијаспора и друге ствари (Нови Сад 2008). У центру ауторове пажње налазе се: статус јужнословенских имиграната, опозиција властито-туђе, искуство самоће, носталгије, туђинства у мултикултурном канадском друштву, као и потраге за местом насељавања (ситуација номада, питање граница, привременост боравка, однос усељеника према новим појавама и стварима). Посебан предмет о којем се расправља у овом чланку јесте имигрантски покушај очувања матерњег језика као језгра личног идентитета. Важно место у ауторовим разматрањима заузима такође питање памћења и успомена у имигрантској заједници (сећање на изгубљени родни крај као основна стратегија усељеничког бивствовања у туђој земљи).

Кључне речи: Давид Албахари, лутање, Ахасверош, изгнаник, идентитет, дијаспора, странац, туђинац, језик.
\end{abstract}

Са проницљивошћу архивиста истражујемо документе више непостојећег света. Фотографије из породичног албума, копије приватне преписке и насловних страна већ давно објављених књига. Текстуални и фотографски записи којима располажемо чине богати досије уметника Давида Албахарија, мајстора пера и баратања речима. Све што смо скупили подсећа истовремено на галаксију, безброј људских звезда, (jep „svaki je čovek zvezda sama za sebe” (Киш 1992: 52)) јединствених људских створења из породичног и уметничког Албахаријевог круга. Дакле, на основу писмених материјала, слика, те употребних артефаката покушавамо, попут археолога и палеографа, да реконструишемо један непоновљив и давно пропали свет.

Давид Албахари - записујемо све што о њему знамо: рођен 1948. у метохијској Пећи у мешаном, јеврејско-српском браку. Мајка Бојана Живковић, „прави почетак сваке пишчеве приче” била је стуб, језгро и центар породичног живота, гарант успеха, као и искрене, неуморне, поуздане и истрајне љубави према деци и својим јеврејским супрузима. Мајчина љубав, као што

\footnotetext{
"milosz.bukwalt@uwr.edu.pl
} 
доводи Ерих Фром, „,[...] bezuvjetna je afirmacija detetova života i njegovih potreba. [...] Majka je dom odakle smo, ona je priroda, zemlja i ocean" (2000: 59, 67). Црно-бела фотографија из 1938. показује лик младе жене на падини. У оно време Бојана Живковић сигурно још не зна нити предосећа да ће њен зрели живот бити непрекидан низ мука, одрицања и личних губитака. ${ }^{1}$

Пишчев отац Исак ${ }^{2}$, сефардски Јеврејин, исконски одан својој лекарској професији и Хипократовој заклетви, био је током Другог светског рата „заробљеник Вермахта”. Заједно са другим официрима свог разбијеног пука одвожен је, као што читамо у пишчевом досијеу „,[...] sporim vozovima, preko Vojvodine, Hrvatske i Austrije ,[...] u oficirske i druge logore širom cele Nemačke" (Албахари 2010: 4-6). Слика у сепија боји, датирана 1942. годином, показује мушкарца у официрској униформи армије Краљевине Југославије, на левом рамену видљива трака са знаком црвеног крста уместо понижавајуће Давидове звезде. Округле наочаре смештене на истакнутом носу чине Исака Албахарија сличним Едуарду Кону, несталом за време „велике ратне поплаве”, јеврејском оцу Данила Киша. На слици из послератног периода видимо већ човека седе косе, озбиљног и концентрисаног погледа који је, према Албахаријевом сведочанству, представљао тип ,političkog buntovnika, neprijatelja režima, kao i borca bez straha i mane” (Албахари 2010: 4). За своју непослушност и незахвалност према комунистичкој партији плаћао је ипак високу цену изгнанства на метохијску периферију, лутања по варошицама и бањама Србије. Лутање је дакле иманентан део његове јеврејске судбине.

Искуство изгнанства, стрепње, страха пред погромом, те сталне неукорењености у друштвеном кругу потпуно изражава фигура Јеврејина луталице, који нема своје властито место, не живи нигде и никоме не припада те, попут свог саплеменика на познатом Шагаловом платну, лебди у ваздуху. ${ }^{3}$ Кажњен непрекидним лутањем и вечитим ходочашћем (он на Велики

${ }^{1}$ У интервјуу датом Михајлу Пантићу писац посебно место посвећује трагичној судбини своје мајке, што потврђује цитат: „Za vreme [rata], moja majka - koja je rođena u Bosni, a pre rata živela u Zagrebu, u braku sa jednim aškenaskim Jevrejinom - skrivala se sa dva sina po srpskim selima. Njenog muža su u Beogradu, gde su pobegli pred ustašama i nacistima, streljali Nemci. Deca i ona su uspeli da prežive rat, a onda su joj, posle oslobođenja, kada je krenula vozom za Beograd, oba sina poginula u železničkoj nesreći. Posle toga, u Beogradu, srela se sa mojim ocem (koji tada nije bio moj otac) i odlučili su da nastave zajedno, da istraju uprkos tragediji i uspomenama, ali i u potpunom poštovanju i tragedije i uspomena”. Види: Уметник је изгнаник. Са Давидом Албахаријем разговара Михајло Пантић /www.davidalbahari.com/, датум преузимања 13. 11. 2016.

Доказе великог мајчиног пожртвовања према деци и другим људима налазимо такође у Албахаријевом роману Мамац што потврђује цитат: „,...] Ništa se nije činilo zbog nje, za nju, već je ona sve činila za druge. Sve se u nju ulivalo, svaka nedaća i svaki neuspeh, svako trpljenje i svako stradanje. Donald bi za nju rekao da je poput velikog gromobrana, da se svako pražnjenje mračnih energija prenosilo u nju, da je štrčala nad nama spremna da sagori, samo da bi nas sačuvala" (Албахари 2005: 14).

${ }^{2}$ Омиљеном оцу писац је посветио роман Цинк. У њему је Давид Албахари представио последње тренутке очевог живота, који чине ,lečenje, odustajanje od lečenja, povratak, priprema za umiranje, sama smrt i rabinova ruka" (Албахари 2004: 108).

${ }^{3}$ Упореди Шагалову слику Изнад Витебска. Ово платно насликано 1914. године после повратка уметника у витепски завичај, представља Јеврејина луталицу са врећом и штапом, који лебди у ваздуху изнад снегом покривених градских кућица. Посебну пажњу заслужује друга Шагалова слика, под насловом Сећање (1914), која показује погрбљеног лутајућег Јеврејина са кућицом превезаном око леђа. 
петак није дозволио Христу да се одмори на прагу његове куће и одрекао се званично његове науке) митски старац са дугом брадом, штапом у руци и врећом на леђима гледа са стране људске радости и туге, нигде не може да нађе мира, стално се преноси с једног места на друго, чекајући крај света. Ова фигура подсећа на уклету особу која, према легенди, доноси несрећу у крајеве кроз које путује. Она такође симболизује проклету судбину јеврејског народа који, лишен властите отаџбине, лута по свету тражећи непрестано своје место на земљи. ${ }^{4}$ Ахасверош (Лутајући Јеврејин), како доказује Мија Рајнер, ,[...] objašnjava prisutnost Jevreja u Evropi, njihovu različitost od lokalnog stanovništva, mobilnost i nepripadanje" (2005: 1-2).

А мудар и човекољубив Исак једног дана добио је сина и назвао га је Давид, што на језику „изабраног Божјег народа” значи ,љубљен” или „вољен” (Босанац 1984: 229). Тај је Давид остао писац светског гласа, мајстор невезаног слога, чије су кратке приче, романи и есеји преведени на шеснаест светских језика. Он је познат и по својим стихотворењима, које, како тврди, формира једино у кратким периодима „dok prozni anđeli ćute”. ${ }^{5}$ Паметан и даровит Исаков наследник савршено је такође савладао уметност транслације, о чему сведоче бројни преводи прозних и драмских остварења из пера Сола Белоуа, Владимира Набокова, Маргарет Етвуд, Исака Башевиса Сингера, Томаса Пинчона, Сема Шепарда, Керил Черчил, Џејсона Шермана и других.

Мушки потомак, попут свог оца и његових предака, непрестано лута по светским друмовима. Живот тог вечног изгнаника стално је трагање за нечим или неким новим. Ову неизбежну поновљивост лоше јеврејске судбине Данило Киш упоређује са „понорницом”, тајанственом, тихом и невидљивом реком исте семитске крви. ${ }^{6}$ Пратимо дакле тог Исаковог сина на многобројним стазама његовог немирног живота. Примећујемо његов лик како корача улицама Ћуприје, омиљеног Земуна, Београда, Врњачке Бање, Атине, Хајфе, Јерусалима, Тел Авива, Бирмингема, Единбурга, Лондона, Сарајева, Сарваша, Берлина, Келна, Ванкувера, Квебек Ситија, Монтреала и најзад Калгарија, где се задржао на дуже време да исприча радозналим људима своју породичну историју, јер према пишчевом сведочанству:

Odlazak za Kanadu plod je slučajnosti, ali odmah sečovek može zapitati da lije bilo šta slučajno? Bilokako bilo, kada sam polazio u jesen 1994. godine, doista nisam verovao daćemo se u Kanadi zadržati više od godinu dana. Ispalo je drugačije prvo zbog toga što sam ja dobio jednu stipendiju za pisanje, potom je i moja supruga dobila posao, povratak je odložen, avionske karte su bačene,

\footnotetext{
${ }^{4}$ На исту тему погледај такође Панас 1992: 1103.

${ }^{5}$ Види: Уметник је изгнаник. Званичан сајт Давида Албахарија /www.davidalbahari.com/, датум преузимања 13.11.2016.

6 У познатој причи „Игра” из збирке Рани јади Киш показује заједничке елементе судбине мушких представника јеврејске породице Кон што потврђује цитат: „[...] Човек провири кроз кључаоницу и помисли То није он, није Андреас. Дуго још је стајао тако повијен, мислећи То није Андреас. [...] Ово морам да покажем Марији. [...] Морам показати Марији Макса Ахашвероша, трговца гушчијим перјем. Треба да њој покажем како теку понорнице крви. Како Андреас није заправо њен Плави Дечко (како она мисли), него његова крв, унук Макса Лутајућег. [...] Њен Плави Дечко, њен Андреас нуди муштеријама и иде од слике до слике, као да лута кроз векове” (Киш 1993: 15).
} 
deca su pošla u školu i tako odjednom, premda je sve išlo postepeno, shvatili smo da smo sada ovde. [...] Ne nameravam niti pokušavam da postanem deo ovdašnje književnosti; sedim, jednostavno, na ovoj velikoj daljini od mog rodnog kraja i jezika, osluškujem taj jezik i pišem knjige.?

Сећања и утиске из свакодневице у граду помешаних језика, култура и менталитета (јер овде на улицама урбаног центра провинције Алберта истовремено звучању речи артикулисане на француском, енглеском, шпанском, украјинском, кинеском) сабрао је, међу другима, у књигу чувених есеја Дијаспора и друге ствари. Та кратка и прецизна књижевна форма омогућила је писцу луталици да увереним језиком изрази свој сопствени став о судбини и искуствима усељеника на канадској, обећаној земљи. Као представник етничке и уметничке дијаспоре Албахари је веома брзо стекао увид у политичка, социјална и културна збивања у Канади. Посебну пажњу привлачи такође пишчево добро знање историје канадске државе, њеног законодавства, уметности, понашања и морала. Своје судове и запажања Албахари обогаћује бројним фрагментима књижевних, филозофских, социолошких те антрополошких дела из пера Бертолда Брехта, Франца Кафке, Хјуа Макленана и других.

Богата Албахаријева рефлексија обухвата пре свега питања везана за политику мултикултурализма. Као странац Албахари хоће хитно и прецизно да упозна принципе функционисања вишенационалног канадског друштва. Занимају га пре свега феномени необичне „канадске стварности”. Ваља да се на том месту присетимо чињенице да је мултикултурализам у Канади истовремено врста службеног програма и миграцијске политике. Као имиграцијска земља од почетка седамдесетих година Канада води званичну политику мултикултурализма која је одговор на оштар сукоб између „англо-келтске” и „франкофонске” популације. У условима кризе влада је одлучила да се створи тип канадског идентитета, који би се заснивао на принципу „интегративног плурализма”, поштовања културне и етничке разноликости и што је важно „razbijanju diskriminatornih gledišta i zavisti” (Херчак, Чичак-Шанд 1991: 23-24). У исто време канадски Индијанци, у складу са правом на сопствен идентитет и равноправност, добили су статус етничке мањине. Подршку етничким скупинама давале су: Министарство за мултикултурализам, Саветодавни одбор за мултикултурализам као и бројне федералне агенције. Поред тога, етничке заједнице добијале су од федералне владе финансијску помоћ за организацију течајева матерњих језика и културних манифестација ${ }^{8}$. Нови закон о мултикултурализму, прихваћен 1988. године; потврђује једино „,...] ustavno pravo Kanađana, da bez obzira na porijeklo, sačuvaju, razvijaju i međusobno dijele svoje kulturne baštine” (Херчак, Чичак-Шанд 1991: 24).

\footnotetext{
${ }^{7}$ Види: Уметник је изгнаник. Zvaničan sajt Davida Albaharija /www.davidalbahari.com/, datum preuzimanja 13.11.2016.

${ }^{8}$ О мултинационалности канадске федерације говори у свом докторском раду Данијела М. Вуковић Ћаласан. Погледај дисертацију Политика мултикултурализма у времену глобализма на страни /fedorbag.bg.ac.rs/, датум преузимања 13.11.2013.
} 
Као што смо већ рекли, вођен радозналошћу и наивношћу новајлије, Албахари поставља канадским колегама по професији мучна питања о смислу и суштини локалног мултикултурализма. Тако формулисана питања која погађају у саму ствар остају ипак без исцрпљујућег одговора, јер колеге по перу ,[...] zamuckuju, nelagodno se smeškaju ili zapliću u dugačke monologe, preopterećene istorijskim, kulturnim i sociološkim činjenicama" (Албахари 2008: 7). Анализирајући чувену књигу канадског писца Хјуа Макленана Две caмоће (1945) те једну Рилкеову љубавну песму, Албахари, проницљив посматрач, пратилац и коментатор свакодневице канадског друштва, долази до закључка да након Другог светског рата Канада није више само бикултурна француско-енглеска земља него скупина разноврсних етничких група од којих свака поседује неотуђиво право на своју „sopstvenu samoću” (Албахари 2008: 8). Непроменљиве, затворене у културном и религијском смислу, ове су националне мањине заинтересоване једино за извршавање својих послова. То је, дакле, тип „издвојене самоће” која, постојећи сама за себе, зна ипак да поштује друге у складу са обавезујућим нормама и стандардима у мултикултурном друштву. Неповезане заједничким циљевима, идејом културне баштине, „нације-самоће” подсећају, према пишчевом мишљењу, на бомбу успореног дејства или ,paklenu mašinu koja jednom, kad-tad, mora da eksplodira” (Албахари 2008: 8). Бити Канађанин значи, и овде би се требало сложити са Албахаријем, живети у усамљености и празнини.

Такву егзистенцију, проткану носталгијом, горчином разочарања и резигнације, води на канадској земљи немала средина усељеника са простора бивше Југославије. Њихов живот такође пролази у знаку, да дозовемо овде титулу романа Храбалског, „пребучне самоће”. Став балканских имиграната према државној администрацији, систему школства и образовања, месним обичајима и моралу одликује презир, гнев и омаловажавање, тј. средства помоћу којих приморани изгнаник може да ублажи бол, носталгију и меланхолију. Као што запажа Анђелко Милардовић, поменут модел понашања усељеника према домаћој заједници можемо, на социолошком плану, да одредимо као релацију пуну напетости између вањске групе и унутрашње скупине. У негативном односу странаца према домаћинском друштву доминира пре свега непријатељство, дистанцирање, негирање или одлучно одбацивање локалних вредности. У реакцијама супротне групе дају се често запазити нагињање, склоност и пристрасност властитој средини, те диференцијација, дискриминација, стереотипизација, чак и стигматизација чланова вањске тј. најчешће имигрантске стране - закључује хрватски истраживач (Милардовић 2013: 35). Усељеничка критика упућена Канађанима односи се дакле на менталну површност друштва, привременост и брзину живота, немилосрдност послодаваца према радницима, смањивање социјалног осигурања, високе трошкове здравствених услуга, па чак и избегавање „физичког кажњавања" у процесу одгајања и васпитивања деце. 
Горепоменута затвореност ${ }^{9}$ према новом и другачијем не само да не олакшава него, супротно, појачава осећај туге, бесмисла, изолације и одбачености балканских имиграната. Они који су пристигли у Канаду из земље рата, етничких деоба и политичког хаоса (ваља истакнути да је то врста принудне, „нежељене селидбе”) инсистирају пре свега да остану исти, упорни и непроменљиви у сваком аспекту свог изгнаничког живота, што потврђује цитат:

[...] Svako od njih [imigranata] smatra da je [...] svet severnoameričkih vrednosti, izopačen. [...] Ostati isti u tom svetu znači zadržati vrednosti prethodnog sveta, makar se one pretvarale u splet nestvarnih maštarija, u mrežu nostalgičnih uspomena. Živeti u uspomenama, živeti u sećanjima znači verovati u mogućnost da prethodni deo života nije okončan i čak je moguć - [...] jednom, u nekoj nedefinisanoj budućnosti - vratiti se i nastaviti ga. Biti isti [...] znači [u tom slučaju] biti živ (Албахари 2008: 33).

Упркос Хераклитовом упозорењу „да човек ни у једну реку не може да ступа два пута", балкански дошљаци упорно се загњурују у погубну и стајаћу воду чежњи и успомена. Они нити унапређују своје стручне способности, нити савладавају вештине и квалификације потребне за ново занимање, што чини огромну препреку за интеграцију у канадско постиндустријско друштво високообразованих стручњака за технологију. И мада се свет око њих, у складу са правилима Мрачног филозофа, нагло и динамично мења и преображава, они подсећају, према Албахарију, на хероје већ давно објављене и покривене прашином заборављености књиге.

Услов sine qua non трајности усељеничке егзистенције чини (ово је својеврсна стратегија одбране) сећање на завичај, башту детињства, гробља, чланове породице, пре свега ипак на кућу, која је, како доказује Мирча Елијаде центар и оса људског света, место безбедности и сигурности супротстављено спољашњој стварности, чије су главне одлике отвореност, хаос и неодређеност (Елијаде 2003: 205). За имигранте запамћена слика дома је „svetinja” и „nepromenjivo središte porodične historije” (Албахари 2008: 16). За разлику од јужнословенског кућног огњишта ${ }^{10}$, канадска „монтажна зграда" указује једино на практичност урођеника чији номадски живот пролази у знаку спремности за промену посла и места становања. Овдашња ,pokretna i nepostojana [...] baraka”, и ту Албахари дели мишљење својих саплеменика,

\footnotetext{
${ }^{9}$ Према Милардовићу странац је ,,[...] оsoba razapeta između dvaju društava i dviju kultura. Živeći negde između, zapravo nigdje, stran je sebi i drugima. Stranac izaziva zanimanje i čuđenje zbog nerazumijevanja prepreka prouzročenih jezikom. On je dvostruki stranac u tuđoj i svojoj kući. Iz različitih razloga zatekao se u novom društvu kao pripadnik strane kulture. Sa sobom donosi prtljagu kompletnog socijalno-kulturnog naslijeđa, ili svoj osobni i kulturni identitet. Stranac je često zarobljen u vlastitoj kulturi. Njegova zarobljenost prolazi iz nemogućnosti probijanja kuće bitke domaćina. Stranac stoga odlazi u samoizolaciju. U tom smislu on je marginalac ili biće sa ruba društva. Socijalni je rubnik”, у: Милардовић 2013: 41.

${ }^{10}$ Према Сими Тројановићу „[...] огњиште је средиште за крепљење душевне и физичке стране човекове, зборно место за целу породицу, освећени центар за многобројне обичаје, [...] стожер за социјални и религијски живот. „[...] Огњиште је исто што кућа” (Тројановић 1990: 34, 37).
} 
знак је неукорењености, недостатка традиције месног становништва, те привремености боравка на канадском подручју. ${ }^{11}$

Очување матерњег језика у туђој земљи спада у најважнија питања имигрантског живота. Према пишчевом сведочанству за већину усељеника коришћење уредног језика у свакодневној комуникацији представља једино „нужно зло”. Они ипак говоре поквареним језиком, једином својеврсном мешавином матерњег и енглеског. У напорима очувања свог говора досељеници су слични дављеницима за које, како запажа писац: „,[...] stari jezik postaje poslednja slamka, tanana nit koja je jedina u stanju [...] da [ih] sačuva od strahotnog osećaja propadanja" (Албахари 2008: 22). За имигрантску средину „домаћи језик” представља, дакле, основу и језгро културног, индивидуалног или колективног идентитета, суштину и услов постојања. Људски доживљај света је, како сматра Ранко Бугарски, „[...] uslovljen kulturom dok je ona sama uveliko profilisana jezikom" (Бугарски 2005: 16-17). Ова је битка ипак одозго „изгубљена” јер бурно море туђег језика може да прогута све што се налази у његовом обиму и границама. Моћ породичне заједнице, овде се ваља сложити са Албахаријем, ,[...] uvek je slabija od sila šireg društva” (Албахари 2008: 23). Упорно трајање једино у границама сопственог језика води ипак изолацији и гетоизацији појединца, односно целе његове средине. Запамћен језик којим се служе странци у свом „,...] okamenjenom prostoru i vremenu" у већини указује на мртвило, непроменљивост, распадање и коначност једног језика. Из тог гробља властите језичке традиције радо беже ипак деца и млади, чији се став према стварности одликује, за разлику од старих, радозналошћу, као и потребом активног укључивања и учешћа у друштвеним процесима. Истовремено савладавање службеног и других језика отвара им могућност за напредовање у едукацији, условљава пословну каријеру у приватним предузећима, корпорацијама или државној администрацији. За представнике генерације младих имиграната, констатује есејист, „[...] sve varijante pristupa očuvanju ili gubljenju jezika uopšte nisu važne" (Исто: 208). Они се у том мору доминантног енглеског односно француског језика осећају као „рибе у води”. Двојезична и вишејезична едукација младог нараштаја доприноси, дакле, његовом менталном, психолошком и друштвеном развоју, јер, по пишчевим речима,

[...] dvojezično dete je često kreativnije i inventivnije od jednojezičnog [...] Detetu ne predstavlja nikakvu teškoću da istovremeno postoji i raste u dva, pa i više, jezika. Kretanje između jezika podstiče ga da lakše savlada jezičke strukture i pravila, mešajući ih u prvi mah, da bi kasnije precizno znalo o kojem jeziku je reč i sa kojim sagovornikom treba tu reč da koristi (Исто: 208).

Посебну пажњу заслужује Албахаријев став према коришћењу, односно одбацивању доминантног језика у процесу стварања књижевног дела. Ту дилему писац, уосталом врло добар познавалац и преводилац са енглеског

${ }^{11}$ На исти начин Албахари описује канадски дом у чувеном роману Мамаu: , „...] sada sam - kaže pripovedač - u kućici koja je, prema kanadskim merilima, uprkos skromnoj veličini, bila prava kuća, iako se po evropskim merilima, s obzirom na materijal upotrebljen za njenu izgradnju, mogla jedino nazvati barakom" (Албахари 2005: 16). 
језика, дефинитивно решава у корист матерњег говора. И мада је неколико пута, како сам признаје, покушавао да зарони у „море туђег језика” (на пример пишући кратке уметничке текстове уз помоћ речника и правописа), брзо се ипак враћао говору свог родног краја. Преображај у такозваног канадског писца показао се немогућим и залудним због тога што уметник „,...] koji već pronašao je svoj stil u jednom jeziku teško može da pređe na drugi jezik, ma koliko je živeo u njemu" (Исто: 134).

Енглеским се језиком Албахари служи из коначности искључиво у званичним ситуацијама као што су: промоције и сајмови књига, ауторске вечеpe, службена и приватна преписка, сусрети са канадским колегама по професији током књижевних фестивала (на пример у Монтреалу). Да поновимо још једном: у случају писца-избеглице доминантни језик представља само инструмент за друштвену комуникацију, а не материју за уметничко стварање и мишљење.

Дакле, устаљен и уобличен стил одлучујући је и кључни фактор за одређивање националне припадности писца. Давид Албахари спада у немалу групу аутора, добровољних или примораних изгнаника, чија су прозна и песничка остварења написана већином на матерњим језицима. Поред „мајстора” Давида укључују се у њу несумњиво: Јосеф Шкворецки, Исак Б. Сингер, Јосиф Бродски, Чеслав Милош и други. Према Албахаријевом уверењу у историји светске књижевности могу се ипак издвојити ствараоци који су „успешно уобличили стилове у два различита језика”, као што су: Владимир Набоков, Самјуел Бекет и Милан Кундера. Посебну групу чине писци имигранти, попут Конрада и Косињског, који су своја књижевна дела створили одмах на британском и америчком енглеском.

Богата пишчева рефлексија говори такође о условима свакодневног живота у границама модерног града. У жижи ауторовог константног интересовања налази се велика урбана целина, у конкретном случају, канадски Калгари. Писац открива град као место необичне динамике, промена, непрестане гужве, саобраћаја који се овде одвија са великим интензитетом. Овај је простор „паpravljen [jedino] za automobile, nadzemne električne vozove, gradske autobuse. Može da se stekne utisak da u Kalgariju, na tom komadu kanadske obećane zemlje, čovek 'živi tek ponegde'” (Албахари 2008: 122).

Збијена градња облакодера, трговачко-пословних центара и једноспратних боравишних кућа не удаљава се од архитектонских решења карактеристичних за цело северноамеричко подручје. О изузетности метрополе сведочи, дакле, не толико суморна изградња колико непоновљив амбијент очаравајуће природе у облику „бескрајног плаветнила неба, [...] планина на хоризонту и [...] сунчаних дана" (Исто: 133).

Читаочеву пажњу ће привући оригиналан и обиман каталог природних феномена присутан у тексту. Попут филолога стихије воде Предрага Матвејевића, ${ }^{12}$ писац ствара попис локалних метеоролошких појава у облику „сувог и топлог” ветра Шинука, који је своје име добио по индијанском племену, те

12 Упореди Матвејевић 2007. 
разноврсних облака који стижу преко горских ланаца (читање облака врста је прорицања сопствене будућности и представља један од основних облика имигрантске активности), као и снега на врховима Стеновитих планина. Ту ваља још истакнути да Албахаријева прича о природи провинције Алберта представља суму локалних легенди, веровања и стварних елемената.

Према оцени аутора, велику улогу у процесу стварања посебног градског карактера и идентитета одигравају пре свега становници Калгарија који брину о одржавању и појачавању хармоничних односа у градској средини. Није промакло пажњи есејиста да локално друштво показује дубоко поверење и љубазност како према многогодишњим суседима, тако и новим усељеницима, што потврђује цитат: „[...] Ovde mnogi ljudi još uvek ostavljaju svoje kuće otvorene preko dana (katkad i noći), neznanci vas [...] pozdravljaju kad hodate; automobili se zaustavljaju onog trena kad se približite ivici pločnika" - закључуje српски есејист (Албахари 2008: 133).

Албахаријева разматрања обухватају и проблематику културног живота у Канади. Пишчева запажања односе се у највећој мери на модел функционисања локалних књижевних удружења, питање постојања такозваног локалног писца, као и на главне стваралачке теме и мотиве. Према ауторовом мишљењу савремено стање канадске литературе верно одсликава унутрашњу организацију федералне канадске државе. Локални писци, људи неодређених „ситних, етничких или географских идентитета” представници су једино регионалне, а не општенационалне литературе. У оквиру канадског мултикултурализма превладавају уметничка остварења из пера регионалних канадских аутора. Горепоменута завичајна књижевност обухвата, како констатује писац усељеник,

[...] dela ograničenog dometa jer se zasniva na ograničenjima koja sama sebi nameće (lokalni jezik i istorija). Upravo ta dominacija regionalnog i etničkog čini da kanadska književnost [...] i dalje, uprkos izuzetnim pojedinačnim glasovima, pripada književnoj provinciji (Албахари 2008: 119).

Збирку Албахаријевих есеја Дијаспора и друге ствари чине текстови објављивани у канадским, српским и хрватским часописима у периоду између 1995. и 2007. године. У главне теме поменутог тома спадају: питање канадског мултикултурализма, статус странаца у вишенационалној канадској држави и њихове стратегије преживљавања у туђини. Писца-изгнаника заокупља такође проблем двојезичности и мултијезичности југословенских досељеника, свакодневна егзистенција становника модерне метрополе, феномени локалне природе, као и разноврсне форме активности канадске културне средине. 


\section{ЛИТЕРАТУРА}

Албахари 2004: D. Albahari, Cink, (urednici) G. Božović i P. Marković, Beograd: Stubovi kulture.

Албахари 2005: D. Albahari, Mamac, (urednik) G. Božović, Beograd: Stubovi kulture.

Албахари 2008: D. Albahari, Dijaspora i druge stvari, Beograd: Akademska Knjiga.

Албахари 2010: D. Albahari: Pamtivek, (urednik) P. Marković, Beograd: Stubovi kulture.

Босанац 1984: М. Босанац, Prosvjetin imenoslov, Zagreb: Prosvjeta.

Бугарски 2005: R. Bugarski, Jezik i kultura, Beograd: Biblioteka XX vek/Književni krug.

Елијаде 2004: M. Eliade, Sveto i profano, (preveo) Z. Stojanović, Beograd: Alnari.

Киш 1992: D. Kiš, Enciklopedija mrtvih, (predgovor) P. Pijanović, Beograd: Prosveta.

Киш 1993: Д. Киш, Игра, у: Породчни ичиркус. Рани јади, Башта, пепео, Пешчаник, Београд: СК3, 15-28.

Милардовић 2013: A. Milardović, Stranac i društvo. Fenomenologija stranca $i$ ksenofobije, Zagreb: PAN LIBER.

Фром 2000: E. Fromm, Umijeće ljubavi, (preveo) P. Raos, Zagreb: V.B.Z.

Херчак, Чичак-Шанд 1991: E. Herčak, R. Čičak-Chand, Kanada: Multikulturalizam, Migracijske teme, br. 7, 23 i 24.

Матвејевић 2007: P. Matvejević, Mediteranski brevijar. Zagreb: V.B.Z

Панас 1992: W. Panas, Topika judajska, y: Słownik literatury polskiej XX wieku. (pod red.) J. Sławińskiego, Wrocław-Warszawa, Ossolineum, 1103.

Тројановић 1990: С. Тројановић Ватра у обичајима и веровањима српског народа, Београд, Просвета.

\section{ИЗВОРИ СА ИНТЕРНЕТА}

Umetnik je izgnanik. Sa Davidom Albaharijem razgovara Mihajlo Pantić /www. davidalbahari.com/

Рајнер 2005: M. Rajner, Ko je u stvari „Jevrejin lutalica”? na strani /www.makabijada.com/lutalica.htm/

Danijela M. Vuković-Ćalasan, disertacija Politika multikulturalizma u vremenu globalizma na strani /fedorbag.bg.ac.rs/ 


\section{Miłosz Bukwalt}

\section{EXPERIENCE OF DIASPORA IN SELECTED ESSAYS BY DAVID ALBAHARI}

\section{(Summary)}

The subject of analysis in this article are the essays of David Albahari included in the collection entitled Diaspora and other things. The above book consists of the texts published in the Canadian, Serbian and Croatian literary press in the period from 1995 to 2007. In the introductory part of the article, the author attempts to define Canadian multiculturalism. In further part of the argument, the author devotes much space to the daily existence of Yugoslavian immigrants in the area of a multinational Canadian federation marked by loneliness, nostalgia, a sense of alienation and temporariness. The author also discusses the opposition of own (immigrant) and others (local, Canadian) presented in the essays by Albahari. A separate subject of study in the article is the issue of bilingualism, the problem of language and cultural identity preserving and typical for immigrant environment survival strategy based on evoking memories and images of the lost homeland (home, birthplace, friends and family members, own habits and rules). 